\title{
Klasik Osmanlıca Dönemi Bir Tıp Metni: İlm-i Tıbb ve Dil Özellikleri
}

\section{A Classical Ottoman Turkish Medical Manuscript: IIlm-i Tıbb and its Language Features}

\section{Hande ÜNVER ÖZDOĞAN* Vedat KARTALCIK ${ }^{* *}$}

\begin{abstract}
Öz: Tıp yazmaları hem eski tıp anlayışına dayalı bilgileri hem de dönemin tıp literatürüne ait söz varlığını günümüze taşır. Didaktik bir üslupla yazılan sade ve anlaşılır bir dil kullanılan tıp yazmalarının incelenmesi hem tıp tarihi hem dil tarihi araştırmaları için son derece önemlidir. Bu makalede Muhammed bin Hasan tarafından yazılmış Milli Kütüphane Adnan Ötüken İl Halk Kütüphanesi Koleksiyonuna 06 Hk 4453 arşiv numarasıyla kayıtlı İlm-i Tibb adlı Klasik Osmanlı Türkçesi dil özellikleri gösteren yazma eser tanıtılmıştır. Eski tıp anlayışında önemli bir yeri olan hıfzıssıhha konulu bu eser, alanında kıymetli bilgiler sunmaktadır. Yazar eseri önce Arapça yazmış daha sonra Türkçeye çevirmiș ve sekiz başlıkta sağlıklı olma kurallarını anlatmıștır. Makalenin giris bölümünde hıfzıssıhha konusu üzerinde durulmuş ve $\dot{I} l m-i T i b b$ adlı eserin içeriği tanıtılmıştır. Daha sonra eserin fonetik ve morfolojik özellikleri örneklerle açıklanmıştır. Son olarak eserin söz varlığı üzerinde durulmuştur. Böylece yazarının hayatı ve yazıldığı yıl hakkında bilgi bulunamayan bu yazma eserin dil özelliklerini ortaya koymak amaçlanmıştır.
\end{abstract}

Anahtar sözcükler: Tıp Tarihi, Klasik Osmanlı Türkçesi, Muhammed bin Hasan, İlm-i Tıbb

Abstract: Medical writing through centuries brings us both the knowledge that is based on the classical medical approach and the existence of the medical terms pertaining to that era. The study of the medical writing which was written in a didactic style in a simple and clear language at that time is very significant, both for linguistic research and for the history of medicine. In this article, the manuscript IIlm-i T1bb, which is registered in the Adnan Ötüken Public Library Collection in National Library with the archive number $06 \mathrm{Hk} 4453$ which was written by Muhammed bin Hasan in classical Ottoman Turkish language structure is introduced and explained. This book which is concerned with hygiene is very important and had a great role in public health care in classical medical studies and provides us precious knowledge on its field. The author wrote his book first in Arabic than translated it into Turkish and explained the rules for being healthy in eight chapters. The introduction of the article concentrates on the issue of hygiene, and the book İlm-i Tibb's contents are introduced. Then the book's phonetic and morphological features are explained with examples. Finally, the book's vocabulary is focused upon. Thereby this article introduces the language structure and properties of this manuscript whose writer's life and date of composition remain unknown.

Keywords: History of Medical, Classical Ottoman Turkish, Muhammed bin Hasan, İlm-i Tibb

\footnotetext{
* Türkolog, Süleyman Demirel Üniversitesi, Sosyal Bilimler Enstitüsü, Yeni Türk Dili Ana Bilim Dalı, Isparta. hande_unv@hotmail.com

** Yrd. Doç. Dr., Süleyman Demirel Üniversitesi, Fen Edebiyat Fakültesi, Türk Dili ve Edebiyatı Bölümü, Isparta. vedatkartalcik@sdu.edu.tr

Bu makale “Muhammed Bin Hasan ILLM-İ TIBB (İnceleme-Metin-Dizin)” başlıklı yüksek lisans tezinden özetlenerek hazırlanmıştır.
} 
Geleneksel tıbbın bilgi birikimini geçmişten geleceğe taşıyan tıp yazmaları, insanlığın sağlıklı yaşam arayışına doğal reçeteler sunmaktadır. Hacamat, tütsüleme, bitkisel tıp, çeşitli macun ve şerbetlerle tedavi vb. gibi bugün alternatif tıp yöntemleri içinde sayılan pek çok uygulamanın temel bilgileri bu kaynaklarda yer almaktadır. Bu bilgiler modern tıp uygulamalarının gelişmesiyle bugün geri planda kalsalar da halk arasında geleneksel öğretiler olarak varlıklarını sürdürmektedir.

“Akdeniz çevresi ve Yakındoğu'da 5000 yll önce ortaya çıkan tıp sanatı, bir sonraki medeniyete devredilip geliştirilerek, ilk önce Mezopatamya-Misır tıbbı daha sonra Hellen-Roma tıbb daha sonra Íslam tıbb ve en son Rönesans ve sonrasında Avrupa'nın geliştirdiği tıp anlayışı olmak üzere günümüzdeki halini almıştır" (Bayat 2010, 14). Türk tıp tarihi ise; "İslam öncesi Orta Asya dönemi, Orta Asya'da başlayan Selçuklular ve Osmanlılarla gelişen Íslami dönem ve Osmanlıların son dönemlerinde batıya yöneliş ile başlayan çağdaşlaşma dönemi şeklinde üç dönemde ilerlemiştir" (Bayat 2010, 238).

Anadolu'da XIV. yüzyıldan itibaren ilk tıp yazmalarına rastlanır. Beylikler döneminde Türkçeye verilen önemin artması ile telif ve tercüme nitelikli çok sayıda Türkçe eser yazılması tıp yazmalarının da sayısının artmasını sağlamıştır (Şahin 2009, 109). İlk dönem eserlerinin konusunu; genel sağlık bilgileri, hastalık tanımları, hastalıkların çeşitli bitkiler, macunlar, şerbetler, müshiller gibi ilaçlarla hazırlanan tedavileri, çeşitli ilaçların kodeksinden oluşan farmakolojik bilgiler (akrabadinler) ve incelediğimiz eserin de konusu olan hıfzı's-sıhha dediğimiz koruyucu hekimlik bilgileri oluşturur.

Klasik tıp metinlerinde önemli bir yeri olan hıfzı's-sıhha, sağlılı bir yaşam için yapılan faaliyetlerin ve alınan önlemlerin tümü; sağlık bilgisi, hijyen anlamına gelir (TDK sözlük 1998, I/986). Kökeni Arapça olan bu kelimenin yerini günümüzde Fransızcadan dilimize geçen hijyen sözcüğü almıştır (TDK sözlük 1998, I/994). Osmanlı tıbbında hıfzı's-sıhha hava, iklimler, yeme içme, giyim, yaz ve kış sporları, uyku, banyo, kan alma, bedenin ve ruhun dinlendirilmesi gibi geniş manada kullanılıp koruyucu hekimlik bilgileri verirken günümüzde hijyen kelimesi daha özel anlamda kullanılmakta daha çok sağlıklı olmak için gerekli temizlik kurallarından bahsetmektedir.

Hifzı's-sıhha konusu tıp yazmalarında önemli bir yere sahiptir. Yalnız hıfzı's-sıhha konusu üzerine yazılan eserler sayıca fazla olmasa da özellikle eserlerin genel sağlık kurallarından bahseden bölümlerinde bu konu üzerinde durulmuştur. İlk dönem tıp kaynaklarından Mehmed bin Mahmûd-ı Şirvânî'nin 1402-1420 yılları arasında yazdığı düşünülen 30 bölümden oluşan Ya'kubiyye'si (Bayat 2010, 285) ve Sultan Çelebi Mehmed adına yazdığı Sultâniyye adlı eseri hıfzı's-sıhha konusu üzerine yazılmıştır (Kurban 1990, VI). Bunların yanında Aydınoğlu Umur Bey adına 1334-48 yılları arasında Tutmacı adında bir müellif tarafından Farsçadan tercüme edilmiş, mesnevi tarzında 372 beyitlik Tabî‘atnâme adlı eser de koruyucu hekimlik hakkında yazılmıştır (Bayat 2010, 285). Ayrıca İshak bin Murad tarafından yazılmış 2 bölümden oluşan Edviye-i Müfrede'nin 3. bölümü (Canpolat 1973, 29), Sinoplu Mümin bin Mukbil tarafindan yazılmış Zâhire-i Murâdiyye'nin 3. bölümü (Bayat 2010, 289), Abdulvehhab bin Yusuf'un genel tıp bilgisi ve koruyucu hekimlik bilgisi üzerine yazdığı Müntahab-ı fi't-Tıbbı'nın 5. bölümü (Güven 2005, 13) gibi pek çok eserin bölümlerinde yazarlar hıfzı's-sıhha konusunu işlemiştir. Yine Sinoplu Mü'min bin Mukbil'in yazdığı Miftâhü'n-nûr ve Hazâinü's-Sürûr (Şahin 1994), İbn Şerîf'in İbn-i Sina ve İbn-Baytar'dan faydalanarak yazdığı Yâdigâr-ı İbn Şerîf (Küçüker 1994) gibi pek çok eserde koruyucu hekimlik bilgilerine rastlanır.

Hifzı's-sıhha yazmaları geleneksel tıpta hekimlerin esbāb-ı sitte-i żarūriyye diye adlandırdığı, insanın sağlıklı veya hasta olma sebeplerini açıklayan 'zorunlu altı sebep' üzerine 
kurgulanır. "Bu altı sebep; hava, yeme ve içme, bedenin istirahati (sükūn-1 bedeneyn), ruhun dinlenmesi (sükūn-1 nefsānịyen), uyumak ve uyanmak, istifrağ ve ihtibas 'dır" (Elbir 2005, 104).

“Tip tarihinde hastalıklara yaklaşımda, Eski Yunan'da Humoral Patoloji Teorisi, İslam tıbbında ise Ahlat-ı Erbaa olarak bilinen tıbbi düşünce esas alınmıştır; yani insan bedeninde dört temel sıvı (kan, balgam, safra, sevda) olduğu ve hastalıkların bu sivlların vücutta dengesiz dağılımından meydana geldiği ve tedavinin de bu siviların vücutta tekrar dengeli bir hale getirilmesiyle mümkün olduğu anlayışı hakimdir" (Doğan 2015, 907). İbn-i Sina ve dönemin diğer hekimleri insanları bu anlayışa göre dört farklı mizaca yani bünyeye ayırmışlar, sağlıklı yaşam bilgilerini buna göre vermişlerdir. Hıfzı's-sıhha yazmaları da bu anlayışla yazılmış, sağlıklı olma kuralları farklı mizaçlara göre verilmiştir.

\section{Muhammed Bin Hasan ve İlm-i Tibb}

İncelediğimiz İlm-i $T \imath b b$ adlı yazma eser 38 varaktan oluşmaktadır. Kütüphane kayıtlarında verilen bilgilere göre eserin boyutları (dış-iç) 216x142-131x81 mm'dir. Düz yazı şeklinde kaleme alınmıştır. Eserin yalnız ilk sayfası 1b'de altı satır, diğer yaprakların tamamında on birer satır vardır. Şemseli, zencirekli, vişnerengi meşin, sırtı yıpranmış, kapakları ebru kağıt kaplı, şirazesi bozuk bir cildi vardır. Mihrabiye ve serlevha mülevven tezhipli, cetveller, söz başları ve duracaklar yaldızlıdır. Saykallı ince abadi kağıda harekeli nesihle yazılmıştır. Ancak derkenarlar rika ile yazılıdır. İmla özellikleri bakımından da eserin genelinden farklı olan derkenarlar, eserin bir müstensih tarafından yazıya geçirildiğini düşündürmektedir. Ancak farklı bir nüshanın bulunamaması sonucu bu konuda kesin bir şey söylemek mümkün değildir.

Eser Milli Kütüphane Adnan Ötüken İl Halk Kütüphanesi Koleksiyonunda 06 Hk 4453 arşiv numarasıyla kayıtlıdır. Kütüphane kayıtlarında eserin müellifi Mehmed Bin Hasan olarak geçmektedir. Ancak müellifin isminin geçtiği $2 \mathrm{~b} / 18$ nolu satırda ikinci 'mim' harfinin üstünde şedde olmasından (حسن بن محمّل) yazarın isminin Muhammed olduğu açıtır. Çalışmamızda Mehmed Tahir'in Osmanlı Müellifleri, Kâtip Çelebi’nin Keşfü'z Zünûn'u, Mehmed Süreyya'nın Sicil-i Osmanînî’si dahil pek çok kaynağa başvurmamıza rağmen eserin müellifi Muhammed Bin Hasan hakkında bilgiye rastlayamadık. Ayrıca eserin farklı bir nüshası bulunmadığı için bu makalede kullanılan veriler Milli Kütüphanedeki tek nüshaya dayanmaktadır.

Yazar kitabına bu tür eserlerde gelenek olduğu üzere (Elbir 2005, 134) besmele, hamdele ve salvele ile başlamıştır. Hamdele ve salvele satırlarının ardından $2 \mathrm{~b} / 18$ 'de; bu bende-i fakiir ve ża iff Muhammed bin Hasan, cümlesinde kendi adını zikretmiştir. Daha sonra eserinin İslami geleneklere göre yazıldığını söylemiş ve bunu $(2 \mathrm{a} / 8 ; 2 \mathrm{~b} / 24,25,26,27 ; 3 \mathrm{a} / 29,30 ; 3 \mathrm{~b} / 44)$ varak ve satır numaralarındaki ayet ve hadislerle desteklemiştir. Müelleif kitabını yazarken faydalandığı kaynak ve kişilerden övgüyle bahsetmiştir. Bu kaynaklar Türk bilgini İbn-i Sina'nın El-Kanun fi't-Tı $b$ adlı eseri ve Anadolunun İbni Sina'sı olarak bilinen fikı ve tıp bilgini hekim Konyalı Hacı Paşa'nın Şifa'ül-Eskāam adlı eserleridir. Ayrıca yine Arap İslam bilgini Alā'addin elKarşì'nin şerhlerinden ve Selçuklu devri hekimlerinden Necỉbü d d-dīn Semerḳandỉnin telif eserlerinden faydalandığını belirtmiştir. Yazar kitabını dönemin önde gelen tıp kitaplarını okuyup, buradaki bilgileri toplayıp karıştırmak suretiyle oluşturmuştur. Bu bilgiyi şu satırlarda görmemiz mümkündür: "esbāb-1 sitte-i żarūriyye tedbìri üzere lisān-1 'arabìde bir risāle te 'lïf idüp kānundan ve şifäü'l-eskāamdan ve fāż̀l-1 'allāme necībü'd-dīn semerkandī' nün mü‘ ellefătından ḳavāninn-i ḥıfž-1 șị̣hati żabt ve anda derc ve sāyir kütüb-i mu'tebere ve resāyil-i mütedāvilede olan fevāyidden cem' ve harc itdüm...(3b/49-3b/50).

Eserde koruyucu hekimlik bilgileri eski hekimlerin ahlat-1 erbaa teorisi ile ve esbab-1 sitte-i zaruriyye dedikleri sağlıklı olmak için gereken zorunlu 6 sebep üzerine verilmiştir. Esbāb-1 
sitte-i żarūriyye hakkında Arapça bir risale yazdığını söyleyen yazar daha sonra bunu Türkçeye çevirdiğini ve 8 bölüme ayırdığını belirtmektedir: "pes risāle-i mezbūre lisān-1 türkī' ye tercüme idüp sekiz ravżaya taksimm itdüm..." (4a derkenar). Yazarın 2. bölüm başlığı dışında yaldızla yazdığ 18 bölüm şu başlıklardan oluşmaktadır:

1- İnsanın içinde yaşadığı hava; ravża-i ūlā bedenī muhịị olan hevā tedbirindedür. $(4 \mathrm{a} / 53,54)$

2- yiyecek ve içecekler; (6a/100) bölüm başı verilmemiş.

3- hareket ve bedenin dinlenmesi; ravża-i sālișe hareket ve sükūn-1 bedeneyn tedbīindedür $(22 \mathrm{a} / 454,455)$.

4- hareket ve ruhun dinlenmesi; ravża-i rābi`a hareket ve sükūn-1 nefsānīn tedbïrindedür $(24 \mathrm{~b} / 506,507)$.

5- uyku ve uykusuzluk; ravża-i hāmise nevm ve yaḳaẓa tedbīindedür (26a/544).

6- istifrağ ve ihtibas (kusma, boşaltma); ravża-i sādise istifrāìg ve iḥtibās tedbïrindedür $(27 \mathrm{a} / 567)$.

7- cinsel ilişki ve hamam; fì tedbīrü 'l-ḥammām (28a/585).

8- sağlığa faydalı şeyler (fasd, hacamat, misvak ile diş temizleme, giyeceklerin önemi, kay etme ve vebadan korunma); ravża-i sāmine ḥıf̣̂-1 ṣı̣ḥate müte allik olur ba ${ }^{c} \dot{z} 1$ eşyāc tedbīindedür (32a/667-668).

\section{Dil Özellikleri}

\section{İmla ve Fonetik}

Eserde Uygur ve Arap imla geleneklerinin bir arada görüldüğü EAT metinlerinin imlasına benzer imla tutarsızlıklarına sık rastlanır. Aynı sözcük ya da eklerdeki ünlülerin bazen okutucu harflerle bazen de hareke ile yazıldığı görülmektedir. Yani aynı kelime bazen vavlı bazen vavsız ötre, bazen ye ile bazen esre ile, bazen elifle bazen üstünle yazıldığ 1 görülür. Metinde elifin gösterimi de düzenli değildir. $/ A$ ünlüsünün aynı sözcüklerde hem üstünlü elifle, hem medli elifle, hem çekerli elifle yazıldığına rastlanmıştır. Örneğin ön seste 'ay' sözcüğü 2 yerde medli elifle (29b/614, 34b/725), 1 yerde üstünlü elifle (37b/788), 1 yerde ise çekerli elifle yazılmıştır. Yine ön seste 'anun' sözcüğü 1 yerde medli elifle (30b/642), 4 yerde çekerli elifle (7b/d130, 7b/135, 14a/271, 34b/730), 3 yerde de üstünlü elifle (9a/169, 35a/739, 35b/746) gösterilmiştir.

Ünsüzler açısından bakıldığında son ses durumunda /ç/ ünsüzü 1 kelime dışında (iç- 5b/93)) sürekli cim (ج) ile yazılmış, /ç/ şeklinde okunmuştur. / $p /$ ünsüzü son seslerde daima / $/$ / (ب) ile yazılmıştır. Biz bu çalışmada genel temayüllere uyarak kelime sonunda $/ b /$ ile yazılan sesleri $/ p /$ olarak transkribe ettik. Son seste / $p /$ ünsüzü, 1 sözcük dışında (șarp 38a/803) genelde zarf-fiil ekinde kullanılmıştır. / $S /$ ünsüzünde ise İnce sıradan sözcüklerin sin (س) ile kalın sıradan sözcüklerin sat (ص) ile yazımı düzenlidir. / T/ ünsüzü yalnız kalın sıradan sözcüklerde tı (b) ile, ince sıradan sözcüklerde dal (د) ve te (ت) ile yazılmıştır. Dal (د) ve te (ت) ile kalın sıradan sözcüklere de rastlanmıştır.

\section{Ünlüler}

Metnimizde bugün de yazı dilimizde kullanılan 8 ünlü mevcuttur. $a, e, \imath, i, o, \ddot{o}, u, \ddot{u}$. Eserde öteden beri tartışma konusu olan Türkçede kelime başında ve ilk hecedeki bazı /e/'lerin, /e/ ile /i/ arasında dokuzuncu bir ses, kapalı /e/ sesi olmasını destekleyen bir tutarlılığa rastlanmamıştır. Aynı kelimelerin hem /e/ hem /i/ ile yazılan örnekleri vardır. geç 18a/359 giç- 10a/187, ye6b/112 yi- 29a/604. Bunun yanında bugün /e/ ile yazılan pek çok sözcük metnimizde /i/ ile 
yazılmıştır: di-, dinil-, giçe, giç, it-, vir-, yi-.

\section{Ünlü Uyumları}

Türk dilinin en eski yazılı metinlerinden başlayarak günümüzde de Türk dilinin hemen tüm kollarında sağlam bir şekilde işleyen damak uyumu bir tek elma sözcüğü dışında metnimizde de tamdır (Şahin 2009, 113). Ekler açısından bakıldığında damak uyumuna aykırı 2 ek tespit edilmiştir. -ki ve -ken. ET'de kelimelere hem kalın hem ince ünlülü gelebilen bu ekler metnimizde yalnızca ince şekillidir: soyraki 21a derkenar, yaturken 33b/704.

Dudak uyumu Türk dilinin geneli için damak uyumu kadar kuvvetli değildir (Ergin, 2012, 72). Metnimizde de hem kelime tabanında hem ekler neticesinde dudak uyumu günümüz Türkçesinin ve ET'nin gerisindedir. ET'de son seste ve bazı ek başlarında bulunan $/ \dot{g} /$ 'ların Batı Türkçesine geçerken düşmesi sonucu önündeki ünlüyü yuvarlaklaştırması metnimizde de görülmüştür. kapuları, șarusı, yazular, içerü. Yine metnimizde dudak ünsüzleri sonucu yuvarlaklaşma olması dolayısıyla uyuma girmeyen pek çok sözcük vardır. semürd-, semüz, temürhindi. Bazı sözcüklerin ise hem uyum dışı kalmış hem uyuma girmiş örneklerinin bir arada kullanıldığı da görülmüştür. semird-, semürd- $v b$.

Eski Türkçede kelime kökleriyle uyumlu olan bazı eklerin ünlüleri Eski Anadolu Türkçesi döneminde çeşitli etkilerle yuvarlaklaşmış, bazı eklerin ünlüleri de düzleşerek $\imath, i^{\prime}$ ye dönmüştür. (Cin 2011, 74).

Metnimizde EAT'de olduğu gibi her zaman düz ve her zaman yuvarlak ünlülerle kullanılan tek şekilli eklerin bulunması dudak uyumunun bozuk olmasının en önemli sebebidir. Bu duruma sebep olan ekleri şöyle sıralayabiliriz:

EAT metinlerinde bazı ekler daima yuvarlak ünlülüdür. Bu da dudak uyumunun bozulmasına neden olur. Metnimizde de ET'den beri yuvarlak ünlülü bu eklere rastlanmıştır: $+A r U$ (İsimden isim yapma eki), - $m U r$ (Fiilden isim yapma eki), -UK (Fiilden isim yapma eki), -DUr(Fiilden fiil yapma eki) -Ur- (Fiilden fiil yapma eki), -Ur (Geniş zaman eki), $+d U r$ (Bildirme eki), -dUK (Sıfat-fiil eki), -dUKdA (Zarf-fiil eki), -dükçe (Zarf-fiil eki), -(y)U (Zarf-fiil eki).

Bazı ekler ise ET'de düz ünlülü iken EAT metinlerinde yuvarlaklaşmıştır. Metnimizde de bu türden eklere rastlanmıştır: $+l U$ (İsimden isim yapma eki), $+s U z$ (İsimden isim yapma eki), $U$ (Fiilden isim yapma eki), +ümüz (I.Tekil şahıs iyelik eki), $+(n) U \eta$ (İlgi hali eki), $+(U) m$ (Teklik I.şahıs eki ), +inüz (Çokluk II. şahıs eki), -(y)Up (Zarf-fiil eki).

EAT metinlerinde bazı ekler daima düz ünlülüdür. Bu da dudak uyumunun bozulmasına neden olur. Metnimizde de ET'den beri düz ünlülü bu eklere rastlanmıştır: +(s)I(n)+ (Teklik III. şahıs iyelik eki), -mIŞ (Öğrenilen geçmiş zaman eki), -(y)IncA (Zarf-fiil eki).

Bazı ekler ise ET'de yuvarlak ünlülü iken EAT metinlerinde düzleşmiştir. Metnimizde geçen örnekler şunlardır: +in (İsimden isim yapım eki), $+\left(I_{4}\right) n c I$ (İsimden isim yapım eki), $+l I_{4} K / G$ (İsimden isim yapım eki), -ICI (Fiilden isim yapım eki), $-I_{4} l$ (Fiilden fiil yapım eki), $\left(I_{4}\right) n$ (Fiilden fiil yapım eki), -(I)ş- (Fiilden fiil yapım eki), + (y)I (Belirtme hali eki), -ıçaķ (Zarffiil eki).

EAT'den Klasik Osmanlı Türkçesine geçiş özelliği gösterdiğini saptadığımız metnimizde bazı ekler dudak uyumuna girme temayülü gösterir. Metnimizin yazıldığı dönem hakkında bize önemli ipuçları veren bu ekler ise şöyledir: $+l I_{4} K / G$ (İsimden isim yapım eki), $-I_{4}$ n (Fiilden fiil yapım eki), $-I_{4} l$ (Fiilden fiil yapım eki), $-U K$ (Fiilden isim yapım eki), ${ }_{S} U z$ (İsimden isim yapım eki), $-d I$ (Görülen geçmiş zaman eki), -mIŞ (Öğrenilen geçmiş zaman eki). 


\section{Ünsüzler}

\section{Ünsüz Uyumu}

EAT'de ünsüz uyumu yoktur. Baştaki konsonant bakımından bugün çift şekilleri bulunan birçok ek eski devirlerde tek şekillidir. Metnimizde de ünsüz uyumu bozuktur. Bu duruma sebep olan ekler ise şunlardır: $+d A$ (bulunma hali eki): toklıkda $8 \mathrm{a} / 143,+d A n$ (çıkma hali eki): yorgunlıkdan 26b/552, -dI (görülen geçmiş zaman eki): itdüm 36b/775, -dUK (sıfat-fiil eki): içdükleri 36b/768, -dUr (bildirme eki): lāyıḳdur 1b/2, -d- (fiilden fiil yapım eki) : kaynadup 15b/305, dUKdA (zarf-fiil eki): itdükde 21a/432, -dükçe (zarf-fiil eki ): içdükçe 21b/436, +çak (küçültme eki) : ılıçak 30a/632, ıșıçak 5a/81, -ıçak (zarf-fiil eki) olıçak 6b/109.

\section{Ünsüz Değişmeleri}

Metnimizde en sık görülen fonetik hadiselerden biri ünsüz değişmelerinden ötümlüleşmedir.

\section{t// >/d/ ötümlüleşmesi}

EAT'de düzenli bir ses hadisesi olan kelime başı $t>d$ değişmesinden sonra / $d /$ li beklenen bazı kelimeler metnimizde ET’deki gibi /t/'li geçmektedir: temürhindi 20a/413, țatlu 7b/129, țur16a/318, toǵ- 5a/75, tut-19b/398, tok 23a/479, țuz 9b/176.

Sözcük başında $t / t$ s sesinin /d/ ye dönüşme oranı ince sıradan sözcüklerde kalınlara göre daha yüksektir: dahi 3a/31, datlu $6 \mathrm{~b} / 106$, datsuz $7 \mathrm{~b} / 131$, değmez $20 \mathrm{~b} / 424$, degül 17b/348, dek 21a/427, deplü 5a/79, der 23b/487, derle-23b/486.

Metnimizde kelime başı $/ t /$ - $/ t /$ sesinin hem ötümlü hem ötümsüz şekliyle kullanıldığ bir tek sözcük vardır. $\mathrm{Bu}$ sözcük 10 yerde ötümlü şekliyle yazılırken 2 yerde ötümsüz olarak yazılmıştır: datlu 6b/106, țatlu $7 \mathrm{~b} / 129$.

Sözcük içinde ise genellikle oldurganlık-ettirgenlik eki -t- ile genişlemiş gövdelerde ya da kendisinden sonra bir ünlü geldiği için geçici $-/ t /->-/ d /$ - ötümlüleşmelerine rastlanmıştır: kocaldur 7b/128, semirdür 10b/200, șovudılmış 36a/763, karışdurmak 36b/769, ıșıdup 29a/610, aydur $36 \mathrm{~b} / 774$, giderür $13 \mathrm{a} / 255$.

Bir kelimede /t/ ünsüzü, geçişme hadisesi sonucu ötümlüleşerek kalıcı değişikliğe uğramıştır: kentü > kendü 8b/159.

Bir kelimede ise kelime sonu kalıcı $t>d$ değişimine rastlanmıştır: süd $7 \mathrm{~b} / 136$.

\section{/k/ > g/ ötümlüleşmesi}

Eski yazıda $/ \mathrm{k} / \mathrm{ve} / \mathrm{g} / \mathrm{seslerinin}$ aynı işaretle gösterilmesi bu değişikliğin tam olarak ne zaman olduğunu bilmemize imkan vermese de Batı Türkçesinin başlangıcında olduğu düşünülmektedir

(Ergin 2012, 85). EAT'de düzenli bir ses hadisesi olan $/ \mathrm{k}-\mathrm{s} / \mathrm{g}$-/ değişmesinden sonra $/ g / \mathrm{li}$ beklenen bazı kelimeler metnimizde ET'deki gibi /k/'li geçmektedir. Bugünkü Türkçeyi esas alarak okuduğumuz bu sözcükler şöyledir: keklik 6a/105, kimesne 10b/195, kendü 8b/159, kimse 12b/238, kepek 9b/178, köz 12b/238, kes-15a/299, küçük 34b/731, kim 9b/174, kürk $32 \mathrm{~b} / 687$.

/k/ sesinin ötümlüleştiği sözcükler ise şöyledir: gec 18a/359, gir- 29b/612, gel-18b/379, girici 29b/621, gemi 24b/504, giril-14a/271, genç 11a/210, göğ̈̈s 13b/268, gerek $21 \mathrm{a} / 435$, göl 12a/233, getür- 35a/733, gölcükler 19a/381, gevşek 18b/373, gölge 10a/186, gevşe- 32b/685, gönül 20a/411, geyecek 29a/603, gibi 8b/160, giç 10a/187, gündiz 26b/556, giçe $26 \mathrm{~b} / 555$, güzel 13a/252, gider-13a/255, geyecek 29a/603, göre 29b/616, geyik 11b/217, göz 24a/496, gibi $8 \mathrm{~b} / 160$, gün $5 \mathrm{a} / 75$.

Metnimizde kelime içi $/-k-/>/-g$-/ ötümlüleşmesi düzenlidir. Genellikle sonu $/ k /$ ile biten 
sözcükler ünlü ile başlayan ek aldıklarında gramerlik -/k/->-/g/- ötümlüleşmesine rastlanmıştır: çekirdeginden 14a/280, derlemege 23b/486, dinlenmegiçündür 22b/467, dökülmege 5b/90, etmegi 6a/104, içmegi 19b/399, issiligine 15a/293, itdügi 5b/85, öksürügi 32a/677, pirligi $35 \mathrm{a} / 733$, sevdügi $24 \mathrm{a} / 497$, virdüginden $22 \mathrm{~b} / 461$.

\section{-/ḳ/- > -/g்/- ötümlüleşmesi}

Metnimizde $/-k-/>/-\dot{g}$-/ ötümlüleşmesi düzenli olarak tüm kelimelerde görülür. Genellikle $/-k /$ sesinden sonra ünlü ile başlayan bir ek geldiğinde, birkaç yerde ise edatların ekleşmesinden dolayı bu gramerlik ötümlüleşmelere rastlanmıştır: aclıga 6b/110, bırag்llup 38a/804, cıkıldugi 1 29b/612, ıșindugindan 32b/680, kabug 1 13b/270, kulaga 37b/797, olmadugindan 16a/322, ovulmaǵa 30a/629, șakınmaga 5b/87, sovuga 28b/596, sovuklugig 19b/402, sușamagi 20b/420, țurmagila 35b/746, yogiken 6b/112.

\section{-/ç/-> -/c/- ötümlüleşmesi}

Metnimizde kelime sonu /c/ ile gösterilen son sesleri, günümüz yazı dilini esas alarak /ç/li okuduk. Bu durumda $/ c ̧-/>/-c /$ değişimi, ünlü ile biten bir ek gelmesi sonucu 1 kelimede görülmüştür: agac1 4b/63.

İki kelimede ise kalıcı /ç-/>/-c/ötümlüleşmelerine rastlanmıştır. ince 13b/270, ocak 11b/22.

Ötümlüleşme dışındaki ses değişmelerinden Batı Türkçesinin ilk zamanlarından itibaren görülen $\mid b-/>/ v-/$ süreklileşmesi metnimizde tamamlanmıştır. Tüm sözcüklerde görülür. var $24 \mathrm{a} / 492$, vir$27 \mathrm{a} / 558$.

Ayrıca EAT'de bazı kelimelerde görülen /s/ sesinin ikizleşmesine metnimizde de rastlanmıştır: așsi 20b/424, issi 5b/91.

\section{Morfolojik Özellikler}

\section{İsim Çekim Ekleri}

\section{Çokluk Eki}

İsimlerin sayı bakımından çokluğunu gösteren +1Ar eki metnimizde 174 yerde geçmektedir.

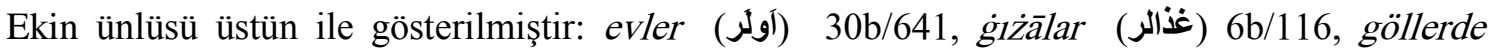
12a/233.

\section{Hal Ekleri}

Yönelme hali +(y)A

Metnimizde 294 yerde yönelme ekine rastlanmıştır. Ekin ünlüsü güzel he ile gösterilmiştir: bökreklere (بؤكركلره) 10b/198, mic deye (معدهيه) 34b/730, șuya (صؤيه) 35a/738.

\section{Belirtme hali +(y)I / +nI}

"EAT'de hem isme, hem iyelik eki almış kelimelere hem de zamirlere gelebilen karakteristik belirtme hali $+(y) I$ 'dır. $+n I$ şekli yalnız zamirlere gelir" (Gülsevin 2011, 31). Metnimizde belirtme haline 252 yerde rastlanmıştır. Ekin ünlüsü ye ile gösterilmiştir: ağnlarn (اغريلرى) 28b/591, elmayi (آلمانيى) 14b/284, șafrayi (صفرايى) 18a/362.

\section{Bulunma hali $+\mathbf{d A}$}

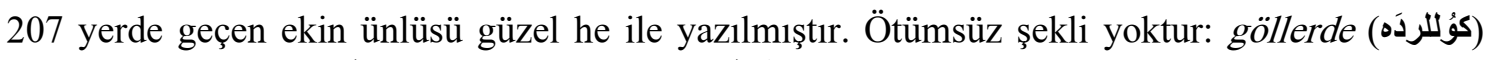

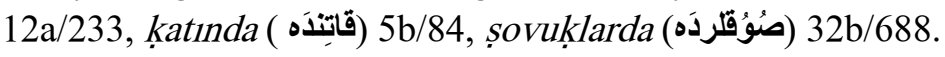




\section{Çıkma hali + dAn}

204 yerde geçen ekin ünlüsü her zaman üstün ile gösterilmiştir. Ekin ötümsüz şekli yoktur. Bu nedenle ünsüz uyumuna girmez: gażabdan (غَضَنَبَنَ) 37a/777, kepeginden (كَنَدَنَ) 9b/178, yorgunlıkdan (يؤرغؤنلقََن) 26b/552.

\section{İlgi Hali $+(\mathbf{n}) \mathrm{Un}$}

İlgi hali eki metnimizde 65 yerde geçer. Ekin ünlüsü daima yuvarlaktır. Nun ve kef ile yazılan

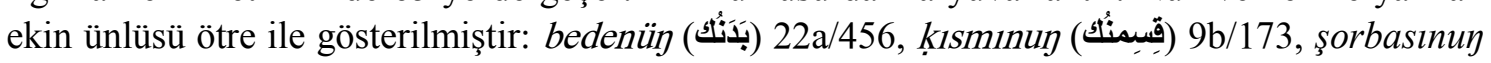
12b/240.

\section{Eşitlik Hali +ca}

Metnimizde 1 sözcükte $1 \mathrm{kez}$ geçen ek ünsüz uyumuna uygun olarak yazılmış ünlüsü güzel he ile gösterilmiştir: fehvasinca (فحواسِنج) 3b/44.

\section{Vasita Hali $+(\mathbf{y})(\mathbf{I}) \mathbf{l a}$}

'İle' edatından ekleşmiş olan bu ek metnimizde asıl vasıta hali durumundadır. 20 yerde geçmektedir. Metnimizde 1 sözcükte ise 'ile' edatının ekleşmesinden farklı bir +la vasıta ekine rastlanmıştır. Bu ek 'iken' anlamı vererek sözcüğü zarf yapmıştır: açla (آجله) 21a/435, birbiriyle 22a/450, olmasiyla (بريريله) 25b/532, yagigyla (اؤلمَسيلهِ) 18a/365.

\section{İyelik Ekleri}

Metnimizde 1 tek kelimede 1. çokluk kişi iyelik çekimine ait örnek vardır. şerī atümüz (شريُشِمْر) 37a/782. Bunun dışındaki örnekler 3.teklik ve çokluk şahıstadır.

Metnimizde teklik üçüncü şahıs iyelik eki 358 defa geçmektedir. Ekin ünlüsü yuvarlak ünlülü kelime tabanlarında dahi daima düzdür. Yazımında ise bazen ye harfi kullanılmakta bazen esre ile gösterilmekte bazen de işaret kullanılmamaktadır. Ayrıca metnimizde 10 yerde bu ek için +(s)I(n) yapısına rastlanmıştır: aggnısın (اغرَسن) 20b/422, eyüsi (ايؤسنى) 12a/229, nezlesi

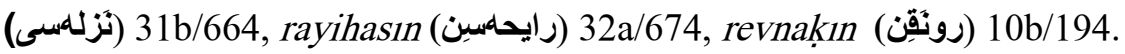

Çokluk üçüncü şahıs iyelik eki +1 ArI metnimizde 60 yerde geçmektedir. Ekin ilk ünlüsü üstünle, ikinci ünlüsü bazen ye ile bazen esre ile yazılmıştır: geyilmeleri (كَلمكلمى 33a/689) öplerine (اؤكلرينه) 14a/274, pencereleri (بنجر 4لرى) 4b/77.

\section{FIIIL ÇEKIMM EKLERİ}

\section{Şahıs Ekleri}

\section{I. teklik şahıs eki}

6 şahısta görülen şahıs eklerinden, metnimizde II. teklik, I. çokluk ve II. çokluk şahıslarda yalnızca birer örneğe rastlanmıştır. Metinde geçen fiiller çoğunlukla III. teklik ve çokluk şahısla çekimlenmiştir.

Metinde asıl I. şahıs eki $+(U) m$ olmasına rağmen bir hadis aktarılırken ek 2 kez $+a m$ şeklinde geçmektedir. Bu durumda ünlüsü üstün ile gösterilmiştir: uyuram (اؤيُونُمَم) 8a/147, uyanuram (اؤيائورَم ) 8a/147.

Metnin asıl I. şahıs eki $+(U) m$ toplam 6 kez geçer. Metnin normal sayfalarında ünlüsü ötre ile gösterilirken 2 kez geçtiği derkenarlarda vavla yazılmıştır: harc itdüm (صورم) derkenar

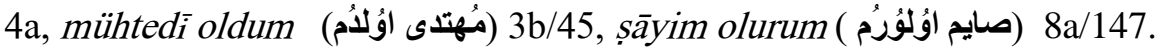




\section{I. çokluk şahıs eki $+1 z$}

Bir tek örneği olan çokluk I. şahıs ekinin ünlüsü dar ünlülü olarak esre ile yazılmıştır: żāmin oluriz (ضامِن اوُلؤرزذ 37b/789.

\section{II. teklik şahıs eki $\Phi$ eksiz}

Bir tek örneğine emir kipinde rastlanmıştır. Fakat teklik II. şahısta emir kipi ek almadığı için metnimizde teklik II. şahsı gösteren bir ek bulunamamıştır: girici ol (كيرجي اول) 29b/621.

\section{II. çokluk şahıs eki +ijüz}

Tek bir örneği olan ekin ilk ünlüsü dardır ve esre ile yazılmıştır. İkinci ünlüsü yuvarlaktır ötreli

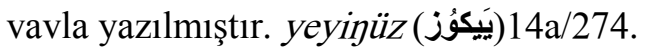

\section{III. teklik şahıs eki $+\Phi$ eksiz}

Metnimizde emir kipi dışında III. teklik şahıs çekimi için özel bir ek yoktur. Fiilere sadece kip ekleri getirilmektedir. Buna göre metinde III. tekil şahısla çekimlenen geniş zamanda 231, görülen geçmiş zamanda 12, ögrenilen geçmiş zamanda 11, istek kipinde 120, şart kipinde 17, emir kipinde 3 olmak üzere toplam 404 fiil vardır: kāmil olsun (كامل اؤلُونَ) 26b/551, vācib oldr 36a/757, güzel ider (مُنفقِل اوُلمَاز) 32a/674,

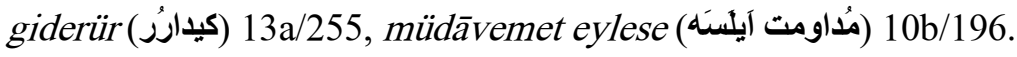

\section{III. çokluk şahıs eki +lAr}

Çokluk III. şahıs eki $+l A r$ metnimizde 50 yerde geçer. Ekin ünlüsü her zaman üstünle

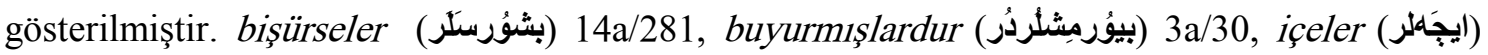

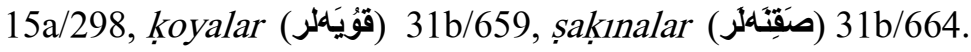

\section{Şekil ve Zaman Ekleri}

\section{Haber Kipleri}

Metnimizde haber kiplerinin geniş zaman, görülen geçmiş zaman ve öğrenilen geçmiş zamanda örneklerine rastlanmıştır.

\section{Geniş Zaman}

Metnimizde geniş zaman ekleri - $A r /-r /-U r$ olumsuzda ise $-m A z$ olmak üzere 4 şekilde toplam 244 kez geçmektedir.

Metnimizde -Ar eki; 101 tanesi 'itmek', 3'ü 'kesmek' fiilinde olmak üzere toplam 104 kez geçer. Ünlüsü üstünle gösterilmiştir: eyü ider (ايدُر) 20a/407, keser (كَرَ) 15a/299.

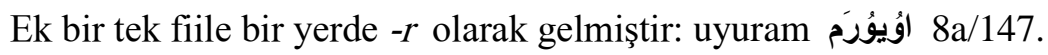

Metnimizde - Ur ekine ise 132 yerde rastlanmıştır. Genellikle ötreli vavla, bazen ise yalnız

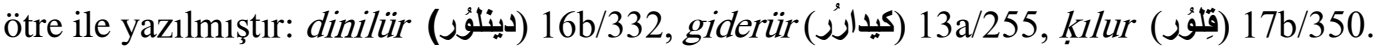

$-\mathrm{mAz}$ eki ise metnimizde geniş zamanın olumsuzu olarak 7 yerde geçmektedir. Ekin ünlüsünün yazımında farklılıklar vardır. Ünlü bazen elifle bazen üstünle yazılmıştır: degmez

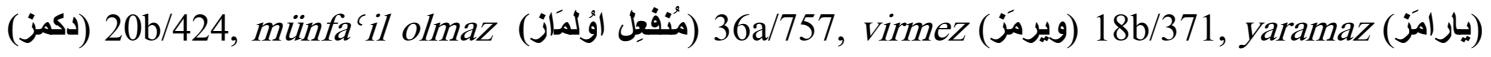
$37 \mathrm{~b} / 795$.

\section{Görülen geçmiş zaman $-\mathbf{d I}_{\mathbf{4}}$}

Görülen geçmiş zaman ekine metnimizde 19 yerde rastlanmıştır. Ek genelde düz ünlülü olarak ye ile yazılırken I. tekil kişi kullanımında yuvarlak ünlülü olduğu görülür. I. tekil şahısta 4 yerde 
(1 oldum, 3 itdüm) geçen ekin ünlüsü 2 yerde vavla 2 yerde ötre ile yazılmıştır: buyurdılar

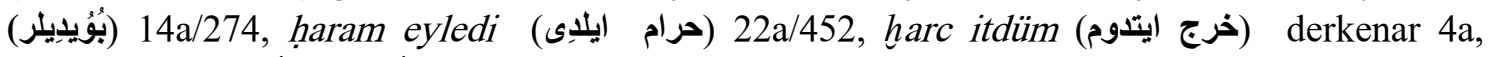

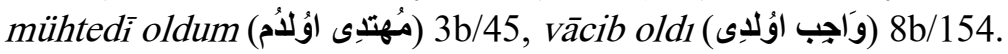

\section{Öğrenilen geçmiş zaman $-\mathbf{m I}_{2} \mathbf{s}_{\text {ş }}$}

23 yerde geçen ekin yuvarlak ünlülü yazımı yoktur. Her zaman düz ünlü ile yazılmış ve ünlüsü

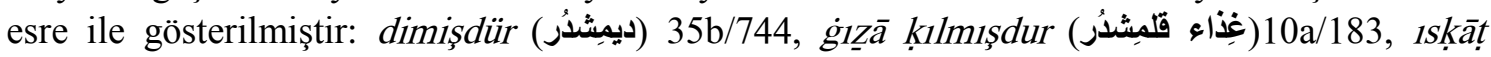

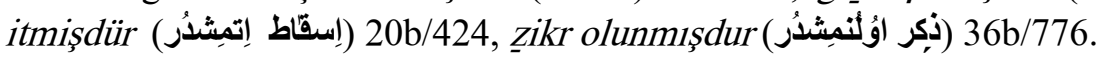

\section{Tasarlama Kipleri}

Metnimizde de dört başlıkta incelediğimiz tasarlama kiplerinden yalnız istek ve şart çekiminde özel bir eke rastlanmıştır.

\section{İstek kipi -(y)A}

İstek kipi, özellikle gelecek zaman için özel bir ek bulunmayan metnimizde de gelecek ifadesi vererek en sık kullanılan dilek kipidir. 146 yerde geçen ekin ünlüsü olumluda her zaman üstünlü

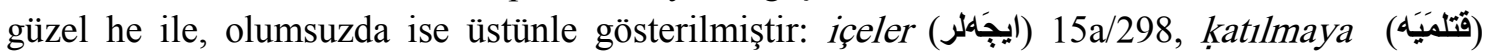

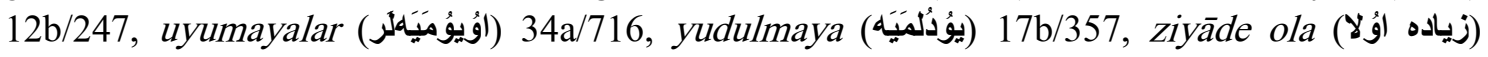
$29 \mathrm{a} / 604$.

\section{Şart kipi -sA}

Metnimizde 20 yerde geçen şart kipinin ünlüsü üstünlü güzel he ile yazılmıştır: bişse (دبشَّaَ)

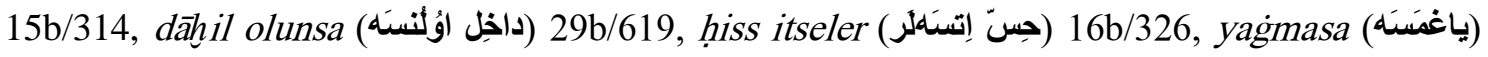
35b/750, yenilse (يَتِلَنَ) 13a/257.

\section{Gereklilik kipi}

Metnimizde gereklilik kipini karşılayan özel bir ek yoktur. Gereklilik anlamı fiillerde $-m A K$ gerekdür (مَقكَركَُر) kalıbı, isimlerde ise gerekdür (كَرَكدُر) sözcükleri getirilerek sağlanmıştır. Metinde -mAK gerek kalıbı 6 kez, gerekdür şekli ise 15 kez geçer: gerekdür 4a/60, hažer gerekdür 29a/607, uyumak gerekdür 26b/556, yenilmek gerekdür 13a/254.

\section{Emir Kipi}

Özel bir eki olmayan emir kipi metnimizde de şahıs çekimine girerek emir anlamı vermiştir. Metnimizde emir kipine II. teklik şahısta 1, III. teklik şahısta 3, II. çokluk şahısta 1 yerde olmak üzere 3 şahıs çekiminde toplam 5 kez rastlanmıştır: girici ol (كيرجي اؤل) 29b/621, kāmil olsun

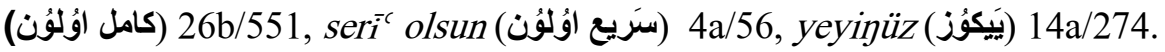

\section{Fiillerin Birleşik Çekimleri}

Metnimizde hikaye birleşik çekiminde 1, şart birleşik çekiminde 9 örneğe rastlanmıştır. Rivayet

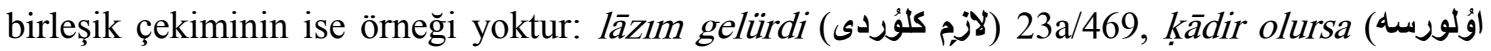

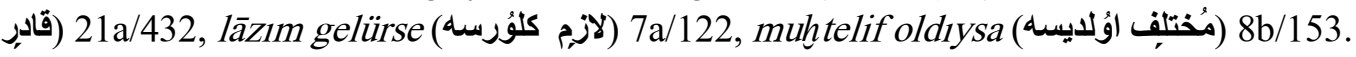

\section{Ek fiil}

Metnimizde ek filin yalnızca geniş zaman III. teklik şahısta örneklerine rastlanmıştır. Bu durumda, isimleri fiil çekimine sokması dışında öğrenilen geçmiş zaman kipinden sonra gelerek kesinlik anlamı katma işleviyle de kullanılmıştır. $+d U r$ şeklinde her zaman yuvarlak yazılan ve ünlü uyumu dışında kalan eke $162 \mathrm{kez}$ rastlanmıştır. Ekin ünlüsü her zaman ötre ile gösterilmiş- 
tir. Ekin $+d U r U r$ şekline ise bir tek örnekte rastlanmış, bu durumda ilk ünlüsü ötre ile ikinci

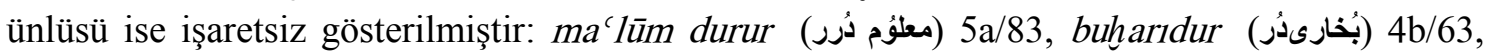

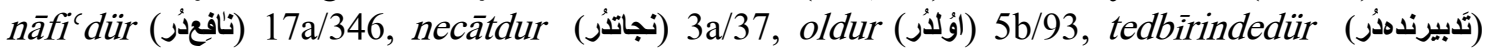

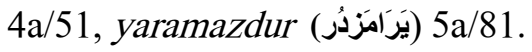

\section{Çekimsiz Fiil Şekilleri}

\section{İsim fiil (Mastar) Ekleri}

Metnimizde isim fiillerden $-m A K$ ve $-m A$ ekleri geçmektedir. $-I S ̧$ ekinin örneği yoktur.

İşlek bir kullanımı olan ve kalıcı isimler de yapabilen - $m A K$ eki metnimizde 113 yerde geçmektedir.

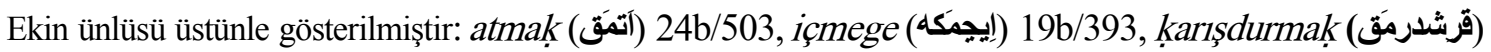

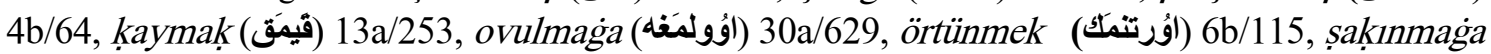
28b/599.

$-m A$ eki ise 19 yerde geçmektedir. Genellikle güzel he ile yazılmasına rağmen elifle ve

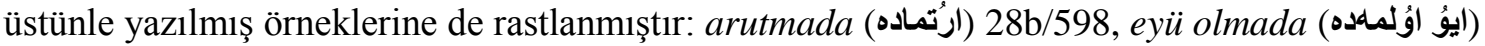

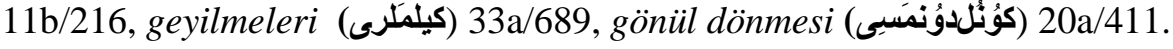

\section{Sıfat-fiil (Partisip) Ekleri}

Metnimizde partisip eklerinden 5 tanesine rastlanmıştır.

-(y)An eki 88 kez geçmektedir. Ekin ünlüsü metnin genelinde üstünle gösterilirken, dönüşlülük

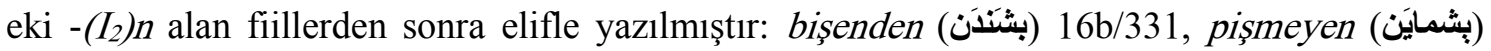
16b/328, kuruyan (تفرؤيَن) 10a/187, tafdil olnan (تفيل اوُلنان) 21b/441.

Metnimizde $-d U K$ partisipi 41 kez geçmektedir. Ek ötümsüz şekliyle kullanıldığında vavsız, ötreli olarak yazılmıştır. $/ \mathrm{k} /-/ \mathrm{k} /$ sesinin ötümlüleştiği örneklerde ise hem vavlı hem vavsız (ötreli)

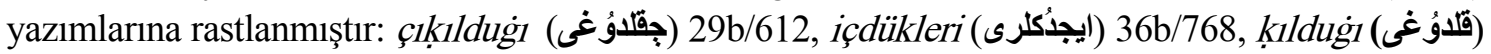

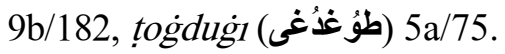

-maz ekine metnimizde yalnız yaramaz kelimesi üzerinde rastlanmıştır. Ek bu kelimede 4 yerde sıfat göreviyle geçmiş, 19 yerde ise kalıcı isim yapmıştır: yaramazdur (isim) (يَرَامزَرُر) $5 \mathrm{a} / 81$, yaramaz (sifat-fiil) (يَرَ) 11b/226.

$-m_{4} S$ geçmiş zaman partisipi metnimizde 28 yerde geçmektedir. Bir kelimede kalıplaşmaya uğrayarak kalıcı isim yapmış ve 7 kez geçmiştir. (yemişlerdür 9b/172+6) Metnimizde geçen öğrenilen geçmiş zaman ekinin yuvarlak biçimi yokken sıfat-fiil olarak 2 yerde -muşs şekli de

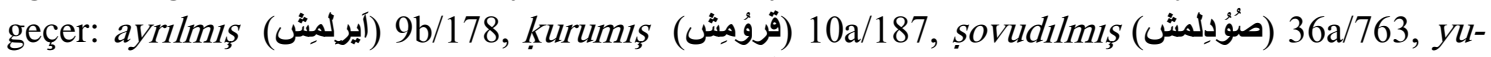
nulmış (يؤنلمِش) 10a/184, mütegayyir olmuş1 (متفير اؤلمُشى) 13b/264.

\section{Zarf-fiil (Gerundium) Ekleri}

Metnimizde basit yapılı zarf fiil eklerinden $-I$, $-I c ̧ A k$, $-(y) U$, - $(y) U p$; birleşik yapılı zarf fiil eklerinden -dUKdA, -dükçe, -(y)IncA, -(y)(I)ken, -mAdIn eklerine rastlanmıştır.

Basit yapılı zarf fiil eklerinden $-I$ eki dahi edatı üzerinde 40 kez geçmektedir. Ünlüsü ye ile yazılmıştır: dahi (نَخى) 3a/31.

Metinde 3 kez olmak fiilinde geçen - IçAk eki, -(y)IncA zarf-fiili ile aynı anlamı vermiştir. İlk ünlüsü esreli ye ile ikincisi üstünle yazılmıştır: hażm olıçaķ (حَم اوُليجقَ) 18a/361.

$-(y) U$ eki 5 kez tekrar eden diyü sözcügünde kalıplaşmış bir zarf olarak kullanılmıştır: diyü 2b/25.

-(y)Up zarf fiili ise 123 ‘-up’, 148 ‘-üp’ olmak üzere toplam 271 yerde geçmektedir. Ötreli 


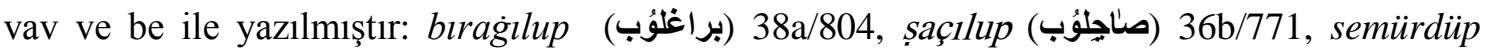
16a/316.

Geçmiş zaman sıfat-fiili üzerine bulunma hal eki gelmesiyle birleşik bir yapı gösteren $-d U K d A$ zarf-fiiline metnimizde 14 yerde rastlanmıştır. Ekin ilk ünlüsü ötre, ikincisi güzel he ile

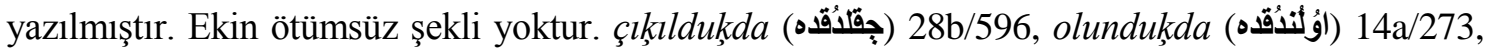
şürū' itdükde (شُُؤع اتدُكده) 21a/432, yenildükde (ينلاُكده) 6b/114.

Eylemin yapılmasına devam ettikçe anlamı veren -dükçe eki metnimizde 1 yerde geçer: içdükçe (ايجُُكجهَ) 21b/436.

-(y)IncA eki '-(y)IncAyA kadar' manasında 2 ekte geçer. Ekin ilk ünlüsü esre, ikincisi güzel he ile yazılmıştır: akınca (آقِنجَ) 23b/487, derleyince (دَرلينجه) 29b/616.

-(y)(I)ken eki / iken zarf fiili 14 yerde geçmektedir. 2 kez geçtiği bir isimde i- ek fiilinin korunmasına rağmen birleşik yazılmış (yogiken 6b/112,19a/389), diğerlerinde ayrı yazılmıştır: yogiken (يؤغيكَ) 6b/112, 19a/389, iken (إيكن) 10b/ 201, hareket iderken (حَركت إيدركن) 17a/337, yaturken (ياتُؤركن) 33b/704.

-madın eki metnimizde bugünkü ‘-madan’ zarf-fiili anlamını vermiştir. Metnimizde tek bir örneği bulunan ekin ilk ünlüsü elifle, ikincisi esreli ye ile yazılmıştır: hażm olmadın ( هضم 6b/111.

\section{Söz Varlı̆̆ı}

İncelediğimiz yazma eser harekeli nesihle yazılmıştır. Metnin ilk sayfalarında hamdele ve salvele bölümlerinde Arapça ve Farsça tamlamalara sık yer verilmiştir. Ancak genel olarak metnin dili sade ve anlaşılırdır. Metinde tıp terimlerinde Arapça üstün olmasına rağmen baş, boyun, ayak, böbrek vb. organ adları Türkçedir. Kuveba, yarekan, hafakan, zükam vb. hastalık adlarının çoğu Arapça olmasına rağmen, öksürük, baş ăgrısı, gönül dönmesi gibi Türkçe hastalık adlarına da rastlanmıştır. Türkçe bitki adlarının yanında Arapça pek çok bitki adı da geçmektedir. Tarihi tıp metinlerinde sık karşılaşılan Arapça hastalık, organ ya da bitki adlarının yanında Türkçe karşılıklarının da yer almasına ise metnimizde rastlanmamıştır.

Eserde halk diline girmemiş pek çok Arapça, Farsça sözcük ve tamlama vardır. Dizinimizdeki 1547 madde başı sözcügün kökenleri ve bu kökenlerin oranları ise şöyledir:

Arapça kökenli sözcükler: \%66.7

Türkçe kökenli sözcükler: \%23.8

Farsça kökenli sözcükler: \%6.1

Arapça ve Farsça sözcüklerin bir araya gelmesiyle oluşan sözcükler: \%2.3

Arapça kökenli sözcüklere Türkçe ek getirilmesiyle oluşan sözcükler: \%0.5

Farsça kökenli sözcüklere Türkçe ek getirilmesiyle oluşan sözcükler: \%0.1

Batı kökenli (Hellence-Yunanca) sözcükler: \%0.5

\section{Dil Özelliklerine Göre Metnin Yazıldığı Yüzyılın Değerlendirilmesi}

EAT'de dudak uyumunun bozuk olmasına rağmen, metnimizde bazı eklerin hem düz hem yuvarlak biçimleri olup dudak uyumuna girme temayülü gösterdiğinden bahsetmiştik. Metnimizdeki bu ekleri uyuma girme sayılarına göre yüzde olarak belirledik. Böylece EAT'den Klasik Osmanlı Türkçesine geçme sürecinde olduğunu düşündüğümüz metnimizin yazılmış olabileceği dönemi belirlemek istedik. Yavuz Kartallığlu'nun 2005 yılında Gazi Üniversitesi Sosyal Bilimler Enstitüsü’nde tamamladığı ve daha sonra kitap olarak yayımladığı Klasik 
Osmanlı Türkçesinde Eklerin Ses Düzeni (16, 17, 18. Yüzyıllar) adlı çalışmasında Evliya Çelebi Seyahatnamesi ve $16,17,18$. yüzyıllara ait metinlere dayandırarak ulaştığı sonuçlara göre bir değerlendirme yaptık. Buna göre:

$+l I_{4} K / G$ (İsimden isim yapım eki); 16 . yüzyılda yuvarlak tabanlardan sonra \%27, 17. yüzyılda $\% 82$, 18. yüzyılda $\% 46$ oranında dudak uyumuna bağlıdır. Metnimizde ise yuvarlak tabanlı kelimelerden sonra \%18,8 uyumdadır.

-In (Fiilden fiil yapım eki); 16. yüzyılda yuvarlak tabanlardan sonra \%38, 17. yüzyılda $\% 67,18$. yüzyılda $\% 83$ oranında uyumdadır. Metnimizde uyuma girme $\% 46,1$ 'dir.

$-I_{4} l$ (Fiilden fiil yapım eki); yuvarlak tabanlardan sonra 16. yüzyılda \%40, 17. yüzyılda $\% 57,18$. yüzyılda $\% 52$ oranında uyumdadır. Metnimizde bu oran $\% 12,5^{\prime}$ tir.

-UK (Fiilden isim yapım eki); 16. ve 17. yüzyılda \%42 uyumda olan bu ek 18. yüzyılda uyuma girmiştir. Metnimizde $\% 5,4$ uyumdadır.

$+s U z$ (İsimden isim yapım eki); EAT'de yalnızca yuvarlak şekli görülen bu ek düz tabanlardan sonra 16 . yüzyılda $\% 83$, 17. yüzyılda $\% 42$, 18. yüzyılda $\% 90$ uyumdadır. Metnimizde \%8,3 uyumdadır.

-dI (Görülen geçmiş zaman eki); 16. yüzyılda nadiren yuvarlak şekilleri görülen ek 17. yüzy1lda $\% 42$ oranında uyumludur. 18 . yüzyılda ekin ünlüsü hep düzdür. Metnimizde \%15,8 uyumdadır.

-mIş (Öğrenilen geçmiş zaman eki); Bu ek 16. yüzyılda düz ünlülüdür. 17. yüzyı1dan itibaren yuvarlak biçimlerine rastlanır. 18. yüzyılda dudak uyumuna bağlanmıştır. Metnimizde \% 7,1 uyumdadır.

Ayrıca teklik birinci şahıs ekinin -vAn şekli 16. ve 17. yüzyılda seyrek görülürken 17. yüzyılın ortalarından itibaren kullanımdan düşmüştür. Metnimizde ise örneğine rastlanmamıştır. Metnimizde ekin $-A m$ şekli geçmektedir. $-A m$ kullanımı ise 16. yüzyıldan itibaren başlamıştır. Yine $+(U) \eta U z$ çokluk ikinci şahıs emir ekinin ilk ünlüsü 17. yüzyılda düz ünlülü tabanlardan sonra dudak uyumuna bağlı iken ikinci ünlüsü \%25 oranında uyumdadır. Metnimizdeki örneği yeyinüz kelimesinde de ilk ünlüsü uyumdadır ikinci ünlüsü ise yuvarlaktır.

17. yüzyılın ikinci yarısından itibaren kullanımdan düştüğü düşünülen zarf-fiil eklerinden UbAn yapısına metnimizde rastlanmamıştır. -mAdIn zarf-fiil ekinin -mAdAn şekli 16. yüzyıldan itibaren nadiren kullanılmaya başlanmıştır. Ancak 17. yüzyılın son çeyreğinden itibaren -mAdAn değişimi tamamlanmıştır. Metnimizde bir örneği görülen ek -mAdIn şeklinde yazılmıştır. olmadın. -ICAK zarf-fiil eki ise 16. yüzyılda daima düz ünlülüdür. 17. yüzyılda yuvarlak tabanlardan sonra \%33, 18. yüzyılda \% 25 oranında dudak uyumuna bağlıdır. Metnimizde 2 kez geçen ek yuvarlak tabandan sonra düz ünlülü gelmiştir. olıcak.

18. yüzyıldan itibaren $\% 88$ dudak uyumuna bağlandığı düşünülen $+d U r$ bildirme eki, 16 . ve 17. yüzyıllarda çoğunlukla hep yuvarlak şekillidir ve düz tabanlı kelimelerden sonra uyum dış1dır. Ekin $+d U r U r$ biçimi ise 15. yüzyıldan itibaren seyrekleşmiş 18. yüzyılın sonlarında ortadan kalkmıştır. Metnimizde 162 yerde geçen ekin $+d U r U r$ şekline 1 tek örnekte rastlanmıştır. malum durur.

\section{Sonuç}

17. yüzyılda yazılmış olabileceğini düşündüğümüz $I l m-i$ Tlbb adlı eser, Eski Anadolu Türkçesinden Klasik Osmanlı Türkçesine geçiş dönemi dil özellikleri göstermektedir. Tanıtılan bu eser hem dil varlığı hem konusu bakımından araştırmacıları için faydalı olabilecek bilgi birikimine sahiptir. 


\section{KAYNAKÇA}

Bayat A. H. (2010). Tip Tarihi. İstanbul 2010.

Canpolat M. (1973). “XIV. Yüzyılda Yazılmış Değerli Bir Tıp Eseri Edviye-i Müfrede”. Türkoloji Dergisi 5/1 (1973) 21-47.

Cin A (2011). Türk Edebiyatının İlk Yusuf ve Züleyha Hikayesi, Ali'nin Kıssa-yı Yusuf'u. Ankara 2011.

Cin A (2006). “Türkçede +sIz/ sİz Eki Üzerine”. Türk Dili Araştırmaları Belleten 2004/I (2006) 19-43.

Doğan A. T. (2015). “Kitab-1 Tibb-1 Hikmet’te Geçen Yabancı Tıp Terimlerine Türkçe Karşılıklar”. Turkish Studies - International Periodical for the Languages, Literature and History of Turkish or Turkic 10/8 (Spring 2015) 903-918. Ankara 2015.

Doğan Ş. (2009). Terceme-i Akrabadin Sabuncuoğlu Şerefeddin: Giriş-Inceleme-Metin-Dizinler. Yayımlanmamış Doktora Tezi. Sakarya Üniversitesi, Sosyal Bilimler Enstitsüsü, Sakarya 2009.

Elbir Z. G. (2005). “XVII. yy’da Yazılmış Önemli Bir Tıp Kitabı”. BAL-TAM Türklük Bilgisi 2 (2005) 125-137.

Ergin M. (2012). Türk Dil Bilgisi. İstanbul 2012.

Gülsevin G. (2011). Eski Anadolu Türkçesinde Ekler. Ankara 2011.

Güven M. (2005). Abdulvehhâb bin Yusuf'un Müntahab-ı Fi't-Tıbb'ı: Dil İncelemesi-Metin-Dizin. Yayımlanmamış Doktora Tezi. Pamukkale Üniversitesi, Sosyal Bilimler Enstitüsü, Denizli 2005.

Kartallığlu Y. (2011). Klasik Osmanlı Türkçesinde Eklerin Ses Düzeni: 16, 17 ve 18. Yüzyıllar. Ankara 2011.

Kurban F. (1990). Şirvanlı Mahmud Sultaniye: Giriş-Metin-Sözlük. Yayımlanmamış Yüksek Lisans Tezi. Marmara Üniversitesi, İstanbul 1990.

Küçüker P. (1994). Yadigar-ı İbn-i Şerif: Giriş-Metin-Dizin. Yayımlanmamış Doktora Tezi. Fırat Üniversitesi, Sosyal Bilimler Enstitüsü, Elazı̆̆ 1994.

Şahin H. (2009). “Tercüme-i Hülâsâ'nın Bir Nüshası Üzerine”. Turkish Studies International Periodical For the Languages, Literature and History of Turkish or Turkic 4/8 (Fall 2009) 108-132.

TDK Sözlük (1998). Ankara 1998. 